\title{
Class 1a Uveal Melanoma
}

National Cancer Institute

\section{Source}

National Cancer Institute. Class 1a Uveal Melanoma. NCI Thesaurus. Code C111022.

Uveal melanoma with low metastatic risk as defined by gene expression profiling. 